\title{
CULTURAL VALUES, ECONOMIC GROWTH, AND INTERNATIONAL IPO UNDERPRICING: EVIDENCE FROM CHINESE COMPANIES
}

\author{
Peixuan GENG(D, Qingmei TAN(®* \\ College of Management and Economics, Tianjin University, Tianjin, China
}

Received 20 April 2020; accepted 21 October 2020

\begin{abstract}
Listing markets have different cultural backgrounds and experience different economic development. This study examines the impact of cultural values and the moderating effect of economic growth on IPO underpricing issued by Chinese companies in different stock markets. Using a sample of 2429 IPOs issuing in four different stock markets for the 2000-2018 period, the results suggest that in markets with higher power distance or longer-term orientation, IPOs experience higher underpricing; in markets with higher uncertainty avoidance scores, masculinity, individualism, or indulgence, IPOs experience lower underpricing. The greater the multidimensional cultural distance is to the Chinese A-share market, the less underpricing IPOs experience. Economic growth has a significant moderating effect, thereby intensifying or restraining the relationship between culture and IPO underpricing. The additional analysis considering cross-listing companies, and the robustness tests considering alternative measures of culture further support the above conclusions. This study highlights the cultural and economic factors motivating IPO underpricing, can help managers select listing markets from cultural and economic perspective.
\end{abstract}

Keywords: IPO underpricing, cultural values, economic growth, investor behaviour, listing markets, Chinese companies.

JEL Classification: G15.

\section{Introduction}

The motivation for the differences in initial returns on the first day of IPO has been a subject of research for decades. Among those factors, culture in different markets has an explicit or implicit impact on investor behavior and stock issuance, thus, plays a significant role on IPO. Recently, some scholars have tried to focus on the impact of culture on IPO underpricing. Costa et al. (2013) investigate the influence of the Hofstede's six cultural dimensions on IPO underpricing of companies that issue stocks in their own countries, and find that underpricing is significantly higher in countries characterized by lower uncertainty avoidance, or

\footnotetext{
*Corresponding author. E-mail: tanqm@tju.edu.cn
} 
higher power distance and long-term orientation. Cai and Zhu (2015) examine the impact of Hofstede's four cultural dimensions and cultural distance on underpricing issued by foreign companies in U.S., and find that greater cultural differences between foreign issuers and U.S. investors increase underpricing costs. Using the data of listed companies in 44 countries, Chourou et al. (2018) find that issuing companies located in countries with more uncertainty avoidance tend to experience a lower level of underpricing, whereas IPO underpricing in countries with more collectivism, masculinity, and power distance tend to be higher. However, when companies from the same country are listed in different markets, the degrees of the cultural shock on IPO underpricing remain unclear. What will happen to these IPOs?

Furthermore, economic growth plays important role in the stock markets, and has an effect on IPO activity (La Porta et al., 1997; Gupta et al., 2018; Meluzín et al., 2018; Rija, 2019). Companies go public under favorable economic conditions that support their growth and development (Ritter, 1984; Rija, 2019), the number of IPOs is significantly correlated with GDP growth (La Porta et al., 1997; Gupta et al., 2018). Meanwhile, during the bull market, investor perception has been the major factor of IPO underpricing (Cornelli et al., 2006; Zhang et al., 2019). Does the economy have a moderating effect on the relationship between culture and IPO underpricing?

Thus, to answer the question, this study examines Chinese companies. There are three reasons why samples from China offer a unique opportunity to answer these questions. First, China is the largest developing country in the world; most Chinese companies make issuance decisions different from those of developed countries. It provides a distinct, underinvestigated setting for the study. Second, Chinese listed companies offer a natural setting to examine the effects of national cultural values and the moderating effects of economic growth. According to the Wind database, as the end of 2018, 3626 Chinese companies are listed in the Chinese A-share market; 1483 Chinese companies are listed overseas. Third, the listing markets of Chinese companies concentrate on the Chinese A-share market, the $\mathrm{H}$-share market, the U.S. stock market, and the Singapore stock market, and their working mechanism and properties are different. The adoption of the popular book-building system in the A-share market has Chinese characteristics. During the price enquiry process, issuers, investors, and other intermediaries manage to push up the issue price in varying degrees. The $\mathrm{H}$-share market launched the third-generation automatic matching system, which connects investors, exchange participants, other participants, and the central market to trade more efficient. The U.S. market is the first to adopt book-building, which lets underwriters manage investor access to shares, allowing them to reduce risk for both issuers and investors and to control spending on information acquisition (Sherman, 2005). The Singapore market adopts the call market method to open and close the market while the remainder of the day's trading continues to rely on the continuous auction method, which significantly improves the price discovery process and declines day-end price manipulation (Chang et al., 2008). Therefore, based on the behavioral finance theory regarding what investor behaviors are in different cultural background and what actions investors take in response to economic change, the objective is to discuss when companies belonging to the same country issue stocks in different markets, how culture explains the difference in IPO underpricing, and how economic growth moderates the relationship between culture and IPO underpricing. 
Following previous studies (Costa et al., 2013; Cai \& Zhu, 2015; Chourou et al., 2018; Gupta et al., 2018), this study explores whether culture, as defined by Hofstede can explain cross-cultural differences in IPO underpricing. The results suggest a significant relationship between IPO underpricing and culture values. IPOs in markets with higher levels of power distance, or longer-term orientation experience higher levels of underpricing, whereas IPOs in markets with higher uncertainty avoidance, more individualism, more masculinity, or more indulgence experience lower levels of underpricing. Further, the greater the multidimensional cultural distance is from the Chinese A-share market, the less IPO underpricing experienced by companies. It also finds a significant moderating effect of economic growth. Economic growth intensifies the relationships between IPO underpricing and power distance, individualism, and long-term orientation; restrains the effect of uncertainty avoidance, masculinity, and indulgence on IPO underpricing. Meanwhile, economic growth weakens the negative role of cultural distance on IPO underpricing.

This study contributes to the research on IPO underpricing in several ways. First, although the recent stream of studies exploring the role of culture in IPO underpricing (Costa et al., 2013; Cai \& Zhu, 2015; Chourou et al., 2018), no studies have focused on the relationship between different national cultures and IPO underpricing of companies from the same country. Thus, to bridge this gap, a sample of domestic- and overseas-listed companies that belong to the same country is selected, including 334 overseas and 2054 domestic listed Chinese companies. The listing locations are concentrated on the four main markets with different culture backgrounds where companies experienced different levels of IPO underpricing. The significant effect of cultural value on IPO underpricing is demonstrated empirically. Second, these listing markets have experienced different economic developments and growths. Economic growth plays an important role on IPO activity and investor perceptions (La Porta et al., 1997; Gupta et al., 2018; Meluzín et al., 2018; Rija, 2019). Thus, the moderating effect of economic growth on the relationship between culture and IPO underpricing are demonstrated, thereby supplementing to the existing IPO underpricing literature. Third, some companies are listed in more than one market; hence, the IPO underpricing is impacted by multiple cultures. To enrich the conclusions, the cultural indices of cross-listing companies, which are initially issued in Chinese $\mathrm{H}$-share market and then A-share market, are revalued to further demonstrate the role of culture on IPO underpricing and the moderating effect of economic growth. The results of this study help managers select listing markets from cultural and economic perspective.

The rest of this study is organized as follows. Section 1 reviews the relevant literature and develops hypotheses. Section 2 describes the data analyzed and documents the methodology. Section 3 presents the empirical results and additional analysis. Section 4 presents robustness tests, and final part concludes.

\section{Literature review and research hypothesis}

\subsection{The relationship of cultural values with IPO underpricing}

Hofstede and Bond (1984), and Hofstede (2001) developed a national culture with six dimensions: power distance $(P D I)$, uncertainty avoidance $(U A I)$, individualism versus collectivism 
$(I D V)$, masculinity versus femininity (MAS), long-term orientation (LTO), and indulgence versus restraint $(I V R)$ which are used to reveal the relationship among personal behaviors, social values, and national culture. Thus, investor behavior and issuer decisions will be analyzed and the relationship between culture and IPO underpricing from these six aspects will be further discussed.

Power distance is defined as the extent to inequity (Hofstede \& Bond, 1984). In higher power-distance markets with a higher degree of information asymmetry, different access to information causes more conflicts among informed and noise traders, which induces them to request higher stocks returns with speculation (Greenwood \& Jovanovic, 1990; Zhou et al., 2020). Uncertainty avoidance is defined as the degree of risk aversion (Hofstede $\&$ Bond, 1984). In higher uncertainty-avoidance societies, most investors are risk-averse, they may accept lower stocks returns but more dividends as compensation for risky investments. Individualism versus collectivism focuses on the degree to which society reinforces individual or collective achievement and interpersonal relationships (Hofstede \& Bond, 1984). In the higher level of individualism markets, investors have more behavioral and cognitive biases (Lan et al., 2019). In order to eliminate market risks and benefit more from investments, they prefer to reduce stock return volatility, value historical performance and high dividend payout by rational judgments (Che, 2018). Masculinity, as opposed to femininity, is defined as a preference in society for achievement and heroism (Hofstede \& Bond, 1984). In masculine markets, investors are more overconfident so that they display less disposition effect (Zhou et al., 2011) and have more motivations for high dividends (Gupta et al., 2018). Long-term orientation connects the past to current and future actions or challenges (Hofstede \& Bond, 1984). In more long-term-oriented markets, investors are the potential buyers of new stocks based on the attention effect, and obtain capital raises and long-term profits during the IPO process (Barber \& Odean, 2008). Consequently, more interest in a purchase of long-term profits will make investors accept lower dividends in the short period and lower issue prices for future benefits (La Porta et al., 2000; Costa et al., 2013; Massa \& Zhang, 2020). Indulgence versus restraint is essentially a measure of conduct code degree (Hofstede, 2001). Given higher indulgence in markets, the government may reduce incentives to regulate investor behavior; it will be more difficult to have an efficient IPO process (Gupta et al., 2018; Huang et al., 2019). For the compensation of unbalance between supply and demand of stocks, they are willing to purchase stocks with higher dividends.

Thus, when investors value more on higher stocks returns, companies will have higher retained earnings to get better investment opportunities for perquisite consumption and extra benefits (Fidrmuc \& Jacob, 2010; Costa et al., 2013); the stock issuance will be at lower offering prices for higher IPO initial returns. Therefore, listings in these higher power distance or longer-term orientation markets will be likely to offer stocks at lower prices to attract investors. However, when investors value more on higher dividends, issuers are left with lower retained earnings and less opportunities of available options (La Porta et al., 2000; Fidrmuc \& Jacob, 2010; Costa et al., 2013), thus contributing to the issue prices being closer to the real value. Therefore, listing in higher degree of uncertainty avoidance, individualism, masculinity, or indulgence markets ensures lower IPO underpricing. 
Culture is a collective phenomenon that is derived from social environment (Hofstede, 2001). To understand the aggregate influence of cultural value, this study chooses the culture of the Chinese A-share market as benchmark. According to Hofstede and Bond (1984) and Hofstede (2001), the Chinese Mainland is higher on power distance, uncertainty avoidance, masculinity, and long-term orientation. Moreover, it is lower on individualism and indulgence. All the cultural indices, taken together, point to a higher level of IPO underpricing. Therefore, if the cultural distances between listing markets and the Chinese A-share market are short, the resulting IPO underpricing will be great, and vice versa.

For the previously analyzed, hypotheses are developed as follows.

- H1a. Companies have higher IPO underpricing in higher power-distance or long-term-oriented markets.

- H1b. Companies have lower IPO underpricing in higher uncertainty-avoidance, more individualistic, more masculine, or more indulgent markets.

- H1c. Companies have lower IPO underpricing in the markets with a greater cultural distance to the Chinese A-share market.

\subsection{The moderating effect of economic growth}

Discrepancies between investors' psychology, sentiment, information management competence, and even using different evaluation methods could lead to heterogeneous beliefs (Nielsson \& Wójcik, 2016). It is demonstrated that investor sentiment, especially during a bull market, has a systematic impact of stock returns (Cornelli et al., 2006; Zhang et al., 2019). Therefore, economic growth also plays an important role in the stock markets, and has an effect on IPO activity (La Porta et al., 1997; Gupta et al., 2018; Meluzín et al., 2018). The prosperity economy contributes to "hot issue" markets (Ritter, 1984), which are characterized by less frequent price deviations (Lim \& Brooks, 2010), high IPO volumes (La Porta et al., 1997; Gupta et al., 2018), and high levels of initial return (Ritter, 1984; Rija, 2019). This study proposes that economic growth adjusts the effect of cultural values on IPO underpricing. In higher power-distance markets with a higher degree of inequality, the faster the economic growth, the more conflicts there are between informed and noise traders due to the inextricable link between economic development and information asymmetry (Greenwood \& Jovanovic, 1990). Thus, the positive effect of power distance on IPO underpricing is much more pronounced when the economy grows rapidly. In higher uncertainty-avoidance markets, investors tend to be risk-seeking during a bull market. Thus, they are prone to making more risky investments and may require higher initial returns. In this condition, the negative effect of uncertainty avoidance on IPO underpricing is weakened when the economy is better. In the higher level of individualism markets, economic development contributes to high sentiments (McGurk et al., 2020). In this case, the stock prices will be overvalued (Baker \& Wurgler, 2006), thereby resulting in higher issuing prices and lower level IPO underpricing. Consequently, the booming economy strengthens the negative effect of individualism on IPO underpricing. In masculine markets, given the well-being of the market, higher turnover leads to disposition effect (Lakonishok \& Smidt, 1986). That is, the growing economy plays an important role in weakening the negative effect of masculinity on IPO underpricing. In more long-term-oriented markets with the situation of rapid development, companies are 
more willing to convey high-quality signals (Lenz \& Ostrowski, 2005); investors are bullish on stocks with high information quality (Derrien, 2005; Chahine et al., 2020), thus significantly enhancing IPO underpricing. In indulgent markets, the developed economy makes market regulations more efficient and co-ordinates IPO activity. Generally, the increase occurs not only in the closing price on the IPO day but also in the IPO underpricing (Huang et al., 2019). Therefore, economic growth restrains the negative effect of indulgence regarding IPO underpricing. In summary, given all cultural dimensions, the overall moderating effect of economic growth will weaken the negative effect of cultural distance on IPO underpricing. Thus, the following hypotheses are proposed.

- H2a. Economic growth strengthens the effect of power distance, long term orientation, or indulgence on IPO underpricing.

- H2b. Economic growth weakens the effect of uncertainty avoidance, individualism, or masculinity on IPO underpricing.

- H2c. Economic growth weakens the negative effect of cultural distance on IPO underpricing.

\section{Research design and data analysis}

\subsection{Variable measures}

IPO underpricing is the initial return of the IPO, conventionally calculated by taking the difference between the closing price on the IPO listing day and the IPO subscription offering price.

Hofstede's six cultural dimensions (i.e., PDI, UAI, IDV, MAS, LTO, and IVR) are adopted to measure cultural values. Following Kogut and Singh (1988), Eq. (1) is used to calculate the multidimensional culture distance $(C D)$ between Chinese A-share market and the listing markets.

$$
C D_{i}=\frac{\sum_{j=1}^{m}\left(\left(S C D_{i, j}-S C D_{A-\text { share }, j}\right)^{2} / V_{j}\right)}{m},
$$

where $C D_{i}$ is cultural distance for the $i^{\text {th }}$ listing market, $S C D_{i, j}$ is cultural score for the $i^{\text {th }}$ listing market with a $j^{t h}$ cultural dimension, $S C D_{A-\text { share }, j}$ is cultural score for Chinese A-share market with a $j^{\text {th }}$ cultural dimension, and $V_{j}$ is the variance of the $j^{\text {th }}$ cultural dimension, $m$ is the number of cultural dimension.

Economic growth (GDPG) as moderating variable is defined as an index of the year-onyear growth rate of gross domestic product (GDP).

This study also include the set of control variables, including legal system $(L S)$, offer size $(O S)$, offer fund $(O F)$, offer timing $(O T)$, operating age $(O A)$, price-earnings ratio $(P E)$, financial leverage $(L E V)$, Certified public accountant reputation $(C P A)$, and stock exchange (SE). $L S$ is measured by the index of investor protection. $O S$ is the amount of issuing stocks. $O F$ is the amount fund of issuing stocks. $O T$ is the time interval between issuing and listing. $P E$, $R O E$, and $L E V$ are the price-earnings ratio, return on equity ratio, and the asset-liability ratio in the year before the IPO, respectively. CPA is dummy variable equaling 1 if the company 
is audited by the Big Four accounting firms and 0 otherwise. $S E$ is dummy variable of stock exchange. We also control industry effect (IND) and year effect (YEAR).

\subsection{Empirical model}

To test the hypotheses, the standard OLS regression models are carried out as follows.

$$
\begin{gathered}
I P O_{u}=a_{0}+a_{1} S C D_{i}+\sum_{n=2}^{12} a_{n} \times \text { Control }+\varepsilon ; \\
I P O_{u}=a_{0}+a_{1} C D+\sum_{n=2}^{12} a_{n} \times \text { Control }+\varepsilon ; \\
I P O_{u}=a_{0}+a_{1} S C D_{i}+a_{2} G D P G+a_{3} S C D_{i} \times G D P G+\sum_{n=4}^{14} a_{n} \times \text { Control }+\varepsilon ; \\
I P O_{u}=a_{0}+a_{1} C D+a_{2} G D P G+a_{3} C D \times G D P G+\sum_{n=4}^{14} a_{n} \times \text { Control }+\varepsilon .
\end{gathered}
$$

Eqs (2) and (3) test the empirical results of the cultural dimensions and distance; Eqs (4) and (5) test the moderating effect of economic growth. $S C D_{i} \times G D P G$ is the interaction of the $i^{\text {th }}$ cultural dimension and economic growth. $C D \times G D P G$ is the interaction of cultural distance and economic growth. Control stands for control variables.

\subsection{Data analysis}

The initial sample comprises all Chinese Mainland companies that conduct IPOs from 2000 to 2018. Companies in the financial sector and companies with incomplete and abnormal data are excluded, thereby resulting in a total sample of 2429 IPOs. Of the final samples, the listing locations are centered on four markets: 2075 companies are listed on the Chinese A-share market, 286 on the Chinese H-share market, 50 on the U.S. market, and 18 on the Singapore market. The primary data are all collected from the Wind database.

Table 1 summarizes the descriptive statistics of samples for the main regression variables. The mean of $I P O_{u}$ is approximately 0.48 , indicating that the IPOs of most samples are underpriced. The mean of the growth rate of GDP is approximately 0.08 . The mean of LS, OS and $O F$ are 2.57, 17.74 and 20.01, respectively. $O T$ is about 15.51 days on average. Averagely, the time interval between foundation and listing is 9.35 years. Financial characteristics suggest that the samples are with average $P E$ of $42 \%$ and average leverage of $47 \%$. The Big Four accounting firms audit about $11 \%$ of the IPOs. We also summarize the descriptive statistics of submarkets for the main regression variables. The average $I P O_{u}$ of subsamples is 0.54 , $0.11,0.18$, and 0.37 , respectively. The indices of PDI, UAI, IDV, MAS, LTO, and IVR of the four markets are different. The average annual economic growth rate is $0.09,0.04,0.02$, and 0.09 , respectively. The ANOVA value is 103.855 , indicating a significant difference in IPO underpricing, which is considered meaningful for further study. 
Table 1. Descriptive statistics (source: authors calculation)

\begin{tabular}{|l|c|c|c|c|c|c|c|c|}
\hline \multirow{2}{*}{} & \multicolumn{4}{|c|}{ All markets } & $\begin{array}{c}\text { Chinese } \\
\text { A-share } \\
\text { market }\end{array}$ & $\begin{array}{c}\text { Chinese } \\
\text { H-share } \\
\text { market }\end{array}$ & $\begin{array}{c}\text { U.S. } \\
\text { market }\end{array}$ & $\begin{array}{c}\text { Singapore } \\
\text { market }\end{array}$ \\
\cline { 2 - 10 } & Min. & Max. & Mean & S.D. & \multicolumn{5}{|c|}{ Mean } \\
\hline Sample size & 2429 & 2429 & 2429 & 2429 & 2075 & 286 & 50 & 18 \\
\hline IPO & -0.39 & 2.64 & 0.48 & 0.43 & 0.54 & 0.11 & 0.18 & 0.37 \\
\hline PDI & 40.00 & 80.00 & 77.72 & 6.70 & 80.00 & 68.00 & 40.00 & 74.00 \\
\hline UAI & 8.00 & 46.00 & 30.05 & 3.02 & 30.00 & 29.00 & 46.00 & 8.00 \\
\hline IDV & 20.00 & 91.00 & 22.05 & 10.21 & 20.00 & 25.00 & 91.00 & 20.00 \\
\hline MAS & 48.00 & 66.00 & 64.72 & 3.21 & 66.00 & 57.00 & 62.00 & 48.00 \\
\hline LTO & 25.69 & 87.41 & 82.91 & 11.86 & 87.41 & 60.96 & 25.69 & 71.54 \\
\hline IVR & 16.96 & 68.08 & 23.95 & 7.06 & 23.66 & 16.96 & 68.08 & 45.54 \\
\hline CD & 0.00 & 36.05 & 1.29 & 5.45 & 0.00 & 3.46 & 36.05 & 19.33 \\
\hline GDPG & -0.03 & 0.15 & 0.08 & 0.01 & 0.09 & 0.04 & 0.02 & 0.09 \\
\hline LS & 2.33 & 4.00 & 2.57 & 0.35 & 2.33 & 4.00 & 4.00 & 4.00 \\
\hline OS & 12.83 & 24.06 & 17.74 & 1.32 & 17.45 & 19.98 & 17.93 & 14.83 \\
\hline OF & 15.49 & 24.93 & 20.01 & 1.03 & 20.07 & 20.06 & 18.07 & 17.45 \\
\hline OT & 0.00 & 377.00 & 15.51 & 15.27 & 15.21 & 11.80 & 51.1 & 10.28 \\
\hline OA & 0.00 & 31.00 & 9.35 & 5.13 & 10.31 & 3.68 & 4.70 & 2.00 \\
\hline PE & -1.30 & 3.33 & 0.42 & 0.29 & 0.46 & 0.16 & 0.51 & 0.28 \\
\hline LEV & 0.05 & 0.97 & 0.47 & 0.16 & 0.48 & 0.44 & 0.42 & 0.47 \\
\hline CPA & 0.00 & 1.00 & 0.11 & 0.32 & 0.05 & 0.43 & 0.60 & 0.44 \\
\hline One-way ANOVA & & & & & & $103.855^{* * *}$ & \\
\hline
\end{tabular}

Notes: Significance values: ${ }^{\star} p<0.1 ;{ }^{* *}$ represents $p<0.05 ;{ }^{\star * *}$ represents $p<0.01$.

\section{Regression analysis}

\subsection{Regression results}

Models 1 and 5 of Table 2 test the impact of power distance and long-term orientation. The results show that the coefficients of PDI and LTO are significantly positive, suggesting that Chinese companies listed in higher power distance or longer-term orientation markets tend to have higher IPO underpricing, which supports Hypothesis 1a. Models 2, 3, 4, and 6 in Table 2 show that the coefficients of UAI, IDV, MAS and IVR are significantly negative, suggesting that listing in more uncertainty avoidance, individualism, masculinity, or indulgence markets has lower IPO underpricing, which supports Hypothesis 1b. The final model in Table 2 shows that there is significantly negative relationship between $C D$ and $I P O_{u}$, indicating that the larger cultural distance between the Chinese A-share market and the listing market is linked to smaller IPO underpricing, which supports Hypothesis 1c. 
Table 2. Regression results of Hofstede's culture on IPO underpricing (source: authors' calculation)

\begin{tabular}{|c|c|c|c|c|c|c|c|}
\hline The di- & $P D I$ & UAI & $I D V$ & $M A S$ & LTO & $I V R$ & $C D$ \\
\hline $\begin{array}{c}\text { of } \\
\text { Hofstede }\end{array}$ & Model 1 & Model 2 & Model 3 & Model 4 & Model 5 & Model 6 & Model 7 \\
\hline Constant & $\begin{array}{l}3.038^{* * *} \\
(8.551)\end{array}$ & $\begin{array}{l}4.878^{* * *} \\
(20.980)\end{array}$ & $\begin{array}{l}4.686^{* * *} \\
(19.668)\end{array}$ & $\begin{array}{l}8.810^{* * *} \\
(16.747)\end{array}$ & $\begin{array}{l}2.943^{* * *} \\
(8.174)\end{array}$ & $\begin{array}{l}5.138^{* * *} \\
(22.040)\end{array}$ & $\begin{array}{l}4.876^{* * *} \\
(20.660)\end{array}$ \\
\hline$S C D_{i}$ & $\begin{array}{l}0.240^{* * *} \\
(7.620)\end{array}$ & $\begin{array}{c}-0.150^{* * *} \\
(-8.215)\end{array}$ & $\begin{array}{c}-0.149^{* * *} \\
(-7.305)\end{array}$ & $\begin{array}{c}-0.446^{* * *} \\
(-7.873)\end{array}$ & $\begin{array}{l}0.343^{* * *} \\
(7.783)\end{array}$ & $\begin{array}{c}-0.091^{* * *} \\
(-5.259)\end{array}$ & \\
\hline$C D$ & & & & & & & $\begin{array}{c}-0.121^{* * \star} \\
(-5.715)\end{array}$ \\
\hline$L S$ & $\begin{array}{l}-0.687^{* * *} \\
(-10.169)\end{array}$ & $\begin{array}{l}-0.853^{* * *} \\
(-15.766)\end{array}$ & $\begin{array}{l}-0.825^{* * *} \\
(-14.372)\end{array}$ & $\begin{array}{l}-1.295^{* *} \\
(-22.133)\end{array}$ & $\begin{array}{l}-0.565^{* * *} \\
(-7.201)\end{array}$ & $\begin{array}{l}-0.958^{* * *} \\
(-18.495)\end{array}$ & $\begin{array}{l}-0.892^{* * *} \\
(-15.841)\end{array}$ \\
\hline OS & $\begin{array}{l}0.545^{* * *} \\
(17.007)\end{array}$ & $\begin{array}{l}0.616^{* * *} \\
(17.953)\end{array}$ & $\begin{array}{l}0.532^{* * *} \\
(16.695)\end{array}$ & $\begin{array}{l}0.628^{* * *} \\
(17.830)\end{array}$ & $\begin{array}{l}0.553^{\star * *} \\
(17.180)\end{array}$ & $\begin{array}{l}0.487^{\star * \star} \\
(15.189)\end{array}$ & $\begin{array}{l}0.490^{* * *} \\
(15.338)\end{array}$ \\
\hline$O F$ & $\begin{array}{l}-0.669^{* * *} \\
(-25.179)\end{array}$ & $\begin{array}{l}-0.692^{* * *} \\
(-25.481)\end{array}$ & $\begin{array}{l}-0.662^{* * *} \\
(-25.045)\end{array}$ & $\begin{array}{l}-0.691^{* * *} \\
(-25.348)\end{array}$ & $\begin{array}{l}-0.672^{* * *} \\
(-25.251)\end{array}$ & $\begin{array}{l}-0.635^{* * *} \\
(-24.316)\end{array}$ & $\begin{array}{l}-0.638^{* * *} \\
(-24.395)\end{array}$ \\
\hline OT & $\begin{array}{l}0.113^{* * *} \\
(7.248)\end{array}$ & $\begin{array}{l}0.108^{* * *} \\
(7.073)\end{array}$ & $\begin{array}{l}0.112^{* * *} \\
(7.159)\end{array}$ & $\begin{array}{l}0.102^{* * *} \\
(6.744)\end{array}$ & $\begin{array}{l}0.113^{* * *} \\
(7.287)\end{array}$ & $\begin{array}{l}0.100^{* * *} \\
(6.453)\end{array}$ & $\begin{array}{l}0.102^{* * *} \\
(6.545)\end{array}$ \\
\hline$O A$ & $\begin{array}{l}-0.059^{* * *} \\
(-3.405)\end{array}$ & $\begin{array}{c}-0.057^{* * *} \\
(-3.263)\end{array}$ & $\begin{array}{l}-0.060^{* * *} \\
(-3.451)\end{array}$ & $\begin{array}{l}-0.057^{* * *} \\
(-2.524)\end{array}$ & $\begin{array}{l}-0.059^{* * *} \\
(-3.379)\end{array}$ & $\begin{array}{l}-0.064^{* * *} \\
(-3.675)\end{array}$ & $\begin{array}{l}-0.064^{* * *} \\
(-3.653)\end{array}$ \\
\hline$P E$ & $\begin{array}{l}0.513^{* * *} \\
(31.744)\end{array}$ & $\begin{array}{l}0.510^{* * *} \\
(31.751)\end{array}$ & $\begin{array}{l}0.512^{* * *} \\
(31.680)\end{array}$ & $\begin{array}{l}0.508^{* * *} \\
(31.602)\end{array}$ & $\begin{array}{l}0.513^{* * *} \\
(31.775)\end{array}$ & $\begin{array}{l}0.508^{* * *} \\
(31.257)\end{array}$ & $\begin{array}{l}0.508^{* * *} \\
(31.308)\end{array}$ \\
\hline$L E V$ & $\begin{array}{c}0.028^{*} \\
(1.845)\end{array}$ & $\begin{array}{c}0.023 \\
(1.521)\end{array}$ & $\begin{array}{c}0.028^{*} \\
(1.879)\end{array}$ & $\begin{array}{c}0.021 \\
(1.401)\end{array}$ & $\begin{array}{l}0.027^{*} \\
(1.821)\end{array}$ & $\begin{array}{l}0.029^{*} \\
(1.907)\end{array}$ & $\begin{array}{c}0.029^{*} \\
(1.914)\end{array}$ \\
\hline$C P A$ & $\begin{array}{l}0.058^{* * *} \\
(3.312)\end{array}$ & $\begin{array}{l}0.044^{* * *} \\
(2.571)\end{array}$ & $\begin{array}{l}0.059^{* * *} \\
(3.352)\end{array}$ & $\begin{array}{l}0.038^{* *} \\
(2.213)\end{array}$ & $\begin{array}{l}0.057^{* * *} \\
(3.274)\end{array}$ & $\begin{array}{l}0.056^{* * *} \\
(3.185)\end{array}$ & $\begin{array}{l}0.057^{* * *} \\
(3.228)\end{array}$ \\
\hline$S E$ & YES & YES & YES & YES & YES & YES & YES \\
\hline$I N D$ & YES & YES & YES & YES & YES & YES & YES \\
\hline YEAR & YES & YES & YES & YES & YES & YES & YES \\
\hline$F$-statistics & 224.440 & 226.131 & 223.597 & 225.142 & 224.889 & 218.983 & 219.487 \\
\hline $\begin{array}{l}\text { Adjusted } \\
R^{2}\end{array}$ & $50.3 \%$ & $50.5 \%$ & $50.2 \%$ & $50.4 \%$ & $50.4 \%$ & $49.7 \%$ & $49.7 \%$ \\
\hline
\end{tabular}

Notes: The numbers in parentheses are $t$-values. Significance values: ${ }^{\star} p<0.1 ;{ }^{\star \star} p<0.05 ;{ }^{\star *} p<0.01$.

Table 3. The moderating effect of economic growth on Hofstede's cultural dimensions and IPO underpricing (source: authors' calculation)

\begin{tabular}{|c|c|c|c|c|c|c|c|}
\hline \multirow{2}{*}{$\begin{array}{c}\text { The } \\
\text { dimension of } \\
\text { Hofstede }\end{array}$} & $P D I$ & UAI & $I D V$ & MAS & LTO & $I V R$ & $C D$ \\
\hline & Model 1 & Model 2 & Model 3 & Model 4 & Model 5 & Model 6 & Model 7 \\
\hline Constant & $\begin{array}{c}3.409^{* * *} \\
(9.473)\end{array}$ & $\begin{array}{l}5.160^{* * *} \\
(20.469)\end{array}$ & $\begin{array}{l}4.582^{* * *} \\
(19.037)\end{array}$ & $\begin{array}{l}9.913^{* * *} \\
(15.567)\end{array}$ & $\begin{array}{l}3.215^{* * *} \\
(8.867)\end{array}$ & $\begin{array}{l}4.948^{* * *} \\
(20.926)\end{array}$ & $\begin{array}{l}4.895^{* * *} \\
(20.975)\end{array}$ \\
\hline$S C D_{i}$ & $\begin{array}{l}0.157^{* * *} \\
(4.479)\end{array}$ & $\begin{array}{l}-0.179^{* * *} \\
(-7.330)\end{array}$ & $\begin{array}{l}-0.093^{* * *} \\
(-3.309)\end{array}$ & $\begin{array}{l}-0.554^{* * *} \\
(-8.222)\end{array}$ & $\begin{array}{c}0.252^{* * *} \\
(5.394)\end{array}$ & $\begin{array}{l}-0.108^{* * *} \\
(-4.544)\end{array}$ & \\
\hline
\end{tabular}


End of Table 3

\begin{tabular}{|c|c|c|c|c|c|c|c|}
\hline \multirow{2}{*}{$\begin{array}{c}\text { The } \\
\text { dimension of } \\
\text { Hofstede }\end{array}$} & PDI & UAI & $I D V$ & MAS & LTO & $I V R$ & $C D$ \\
\hline & Model 1 & Model 2 & Model 3 & Model 4 & Model 5 & Model 6 & Model 7 \\
\hline$G D P G$ & $\begin{array}{l}-0.776^{* * *} \\
(-3.325)\end{array}$ & $\begin{array}{l}-0.232^{* * *} \\
(-2.469)\end{array}$ & $\begin{array}{l}0.193^{* * *} \\
(3.077)\end{array}$ & $\begin{array}{l}-1.196^{* * *} \\
(-5.157)\end{array}$ & $\begin{array}{l}-0.394^{* *} \\
(-3.249)\end{array}$ & $\begin{array}{c}0.004 \\
(-0.146)\end{array}$ & $\begin{array}{l}0.110^{* * *} \\
(4.502)\end{array}$ \\
\hline$S C D_{i} \times G D P G$ & $\begin{array}{l}0.940^{* * *} \\
(3.693)\end{array}$ & $\begin{array}{l}0.316^{* * *} \\
(3.308)\end{array}$ & $\begin{array}{c}-0.095^{*} \\
(-1.806)\end{array}$ & $\begin{array}{l}1.366^{* * *} \\
(5.495)\end{array}$ & $\begin{array}{l}0.570^{* * *} \\
(3.971)\end{array}$ & $\begin{array}{l}0.104^{*} \\
(1.821)\end{array}$ & \\
\hline$C D$ & & & & & & & $\begin{array}{l}-0.110^{* * *} \\
(-5.184)\end{array}$ \\
\hline$C D \times G P D G$ & & & & & & & $\begin{array}{l}0.146^{* * *} \\
(6.901)\end{array}$ \\
\hline$L S$ & $\begin{array}{c}-0.668^{* * *} \\
(-9.751)\end{array}$ & $\begin{array}{l}-0.840^{* * *} \\
(-15.542)\end{array}$ & $\begin{array}{l}-0.817^{* * *} \\
(-14.209)\end{array}$ & $\begin{array}{l}-1.288^{* *} \\
(-20.942)\end{array}$ & $\begin{array}{l}-0.554^{* *} \\
(-6.945)\end{array}$ & $\begin{array}{l}-0.917^{* * *} \\
(-17.384)\end{array}$ & $\begin{array}{l}-0.960^{* *} \\
(-16.945)\end{array}$ \\
\hline OS & $\begin{array}{l}0.556^{* * *} \\
(17.390)\end{array}$ & $\begin{array}{l}0.585^{* * *} \\
(16.623)\end{array}$ & $\begin{array}{l}0.547^{* * *} \\
(17.124)\end{array}$ & $\begin{array}{c}0.600^{* * *} \\
(17.030)\end{array}$ & $\begin{array}{l}0.559^{* * *} \\
(17.441)\end{array}$ & $\begin{array}{c}0.526^{* * *} \\
(15.625)\end{array}$ & $\begin{array}{c}0.504^{* * *} \\
(15.884)\end{array}$ \\
\hline$O F$ & $\begin{array}{l}-0.679^{* * *} \\
(-25.646)\end{array}$ & $\begin{array}{l}-0.690^{* * *} \\
(-25.499)\end{array}$ & $\begin{array}{l}-0.673^{* * *} \\
(-25.439)\end{array}$ & $\begin{array}{l}-0.695^{* * *} \\
(-25.698)\end{array}$ & $\begin{array}{l}-0.682^{* * \star} \\
(-25.695)\end{array}$ & $\begin{array}{l}-0.660^{* * *} \\
(-24.832)\end{array}$ & $\begin{array}{l}-0.684^{* * *} \\
(-24.959)\end{array}$ \\
\hline OT & $\begin{array}{l}0.115^{* * *} \\
(7.388)\end{array}$ & $\begin{array}{l}0.109^{* \star \star} \\
(7.152)\end{array}$ & $\begin{array}{l}0.114^{* * *} \\
(7.239)\end{array}$ & $\begin{array}{l}0.105^{* * *} \\
(6.995)\end{array}$ & $\begin{array}{l}0.114^{* * *} \\
(7.352)\end{array}$ & $\begin{array}{l}0.100^{* * *} \\
(6.462)\end{array}$ & $\begin{array}{l}0.112^{* * *} \\
(7.238)\end{array}$ \\
\hline$O A$ & $\begin{array}{l}-0.036^{*} \\
(-2.037)\end{array}$ & $\begin{array}{c}-0.046^{* * *} \\
(-2.620)\end{array}$ & $\begin{array}{l}-0.043^{* *} \\
(-2.421)\end{array}$ & $\begin{array}{l}-0.035^{* *} \\
(-2.006)\end{array}$ & $\begin{array}{l}-0.035^{* *} \\
(-1.988)\end{array}$ & $\begin{array}{c}-0.047^{*} \\
(-2.644)\end{array}$ & $\begin{array}{l}-0.037^{* *} \\
(-2.129)\end{array}$ \\
\hline$P E$ & $\begin{array}{l}0.484^{* * *} \\
(28.486)\end{array}$ & $\begin{array}{l}0.495^{* * *} \\
(29.599)\end{array}$ & $\begin{array}{l}0.491^{* * *} \\
(29.163)\end{array}$ & $\begin{array}{c}0.480^{* * *} \\
(28.689)\end{array}$ & $\begin{array}{l}0.482^{* * *} \\
(28.344)\end{array}$ & $\begin{array}{l}0.485^{* * *} \\
(28.975)\end{array}$ & $\begin{array}{l}0.476^{* * *} \\
(28.579)\end{array}$ \\
\hline$L E V$ & $\begin{array}{c}0.016 \\
(1.080)\end{array}$ & $\begin{array}{c}0.014 \\
(0.915)\end{array}$ & $\begin{array}{c}0.018 \\
(1.190)\end{array}$ & $\begin{array}{c}0.009 \\
(0.594)\end{array}$ & $\begin{array}{c}0.016 \\
(1.042)\end{array}$ & $\begin{array}{c}0.018 \\
(1.194)\end{array}$ & $\begin{array}{c}0.014 \\
\nabla 0.957)\end{array}$ \\
\hline$C P A$ & $\begin{array}{l}0.053^{* * *} \\
(3.034)\end{array}$ & $\begin{array}{l}0.053^{* * *} \\
(3.074)\end{array}$ & $\begin{array}{l}0.055^{* * *} \\
(3.143)\end{array}$ & $\begin{array}{l}0.045^{* * *} \\
(2.637)\end{array}$ & $\begin{array}{l}0.052^{* * *} \\
(3.028)\end{array}$ & $\begin{array}{l}0.054^{* * *} \\
(3.037)\end{array}$ & $\begin{array}{l}0.050^{* * *} \\
(2.842)\end{array}$ \\
\hline$S E$ & YES & YES & YES & YES & YES & YES & YES \\
\hline$I N D$ & YES & YES & YES & YES & YES & YES & YES \\
\hline$Y E A R$ & YES & YES & YES & YES & YES & YES & YES \\
\hline$F$-statistics & 194.316 & 194.641 & 192.221 & 196.922 & 194.900 & 189.625 & 197.219 \\
\hline Adjusted $R^{2}$ & $50.9 \%$ & $50.9 \%$ & $50.6 \%$ & $51.2 \%$ & $50.9 \%$ & $50.2 \%$ & $51.2 \%$ \\
\hline
\end{tabular}

Notes: The numbers in parentheses are $t$-values. Significance values: ${ }^{*} p<0.1 ;{ }^{* *} p<0.05 ;{ }^{* *} p<0.01$.

Models 1, 3 and 5 of Table 3 show that the economic growth strengthens the effect of power distance, individualism, or long-term orientation on IPO underpricing. The results support Hypothesis 2a. Models 2, 4, and 6 of Table 3 indicate that the economic growth weakens the effect of uncertain avoidance, masculinity, or indulgence on IPO underpricing. The results support Hypothesis $2 \mathrm{~b}$. Final model of Table 3 shows that the coefficient of $C D^{\star} G D P G$ is significantly positive, indicating that economic growth weakens the negative role of cultural distance on IPO underpricing. Hypothesis $2 \mathrm{c}$ is confirmed. F-statistics are all significant. Considered the limited explanatory and control variables, all adjusted $R^{2}$ are about $50 \%$, while those have no effect on the significance of cultural variables. 


\subsection{Regression discussion}

The positive evidence of $P D I$ dimension confirms that higher power-distance markets mean more conflicts among traders and faster economic growth leads to more conflict (Greenwood \& Jovanovic, 1990), thus, providing more opportunity for speculation and valuing more on returns. Therefore, power distance leads to higher IPO underpricing and economic growth strengthens the positive impact. Regarding the evidence of UAI dimension, listed companies in higher uncertainty-avoidance markets should stabilize stock prices and distribute high dividends to boost investor confidence (Grinblatt \& Hwang, 1989), whereas, riskaverse investors will look forward to undertaking more risks for higher returns with booming economy. Therefore, IPOs are inclined to have lower underpricing, but it will be weakened by the higher rate of economic growth. In terms of the negative effect of $I D V$, investors in individualism markets are more sensitive about losses (Che, 2018; Lan et al., 2019), and economic growth increases the high sentiments of investors (McGurk et al., 2020) contributing to the overvalued stock price (Baker \& Wurgler, 2006). As a result, individualism indicates a willingness to acquire lower initial-day returns and the negative effect is more significant with prosperity. The dimension of MAS is examined in relation to disposition effect. Masculinity has fewer disposition effects (Zhou et al., 2011), which makes investors have more motivations for high dividends (Gupta et al., 2018). However, economic growth makes disposition effect increase (Lakonishok \& Smidt, 1986). Thus, to meet investors' expectations, companies are likely to experience lower IPO underpricing in higher-masculinity markets, whereas the lower is restrained with faster economic growth. The results of LTO that have positive effect are consistent with prospect theory. Once investors have long-term orientation, their focus during the IPO process will be capital for its long-term benefit rather than profits in the short term (Costa et al., 2013). Moreover, with rapid economic development, companies acquire higher reputation. Hence, longer-term orientation leads to higher level of underpricing, and economic growth intensifies the positive impact. The evidence of IVR is explained according to IPO activity. Indulgent markets are more difficult to have an efficient IPO process, whereas economic development contributes to market regulations and co-ordinates IPO activity (Huang et al., 2019). Therefore, indulgence creates a negative relationship with IPO underpricing, yet their negative relationship is weakened by fast-growing economy.

Costa et al. (2013) and Chourou et al. (2018) neglect the comprehensive dimension of national culture. Cai and Zhu (2015) examine the relationship between average underpricing and cultural distance by issuer nationality. In this study, the result of cultural distance dimension that has negative effect on IPO underpricing is similar to that of Cai and Zhu (2015). Chinese A-share market has the highest underpricing in comparison with overseas listing market (the H-share market, the Singapore market, and the U.S. market), thus, the greater cultural distance to Chinese A-share market leads to smaller underpricing. Moreover, rapid economic growth restrains negative effect. All are consistent with hypotheses.

We extend analyses to the case of Chinese companies and take China Railway Construction Corporation Limited (shorted as CRCC) for example. CRCC was listed in the Chinese A-share market and H-share market on March 10 and 13, 2008, with 28.19\% and 12.15\% IPO underpricing, respectively. Compared with cultural values of Chinese mainland, Chinese 
Hong Kong is higher on individualism, and lower on power distance, uncertainty avoidance, masculinity, long-term orientation, and indulgence. Taken all cultural values together, IPO underpricing of CRCC listed in the H-share market was lower than that in the A-share market.

\subsection{Additional analysis}

Among the sample, there exists a unique dataset of 24 cross-listing companies that first issue $\mathrm{H}$-shares and, subsequently, A-shares; consequently, their IPOs are impacted by two kinds of national culture when issuing on the Chinese A-share market. Thus, for the cross-listing companies, it revalues the cultural indices by the average of the cultural indices of the $\mathrm{H}$ share and A-share market and recalculate the cultural distance between the $\mathrm{H}$-share and A-share market using Eq. (2). Then, considering the cross-listing companies, the following analysis re-examine empirical tests by updating the cultural data. Tables 4 and 5 report the results for the additional analysis, consistent with hypotheses.

Table 4. Regression results of additional analysis (source: authors' calculation)

\begin{tabular}{|l|c|c|c|c|c|c|c|}
\hline $\begin{array}{c}\text { The } \\
\text { dimension of } \\
\text { Hofstede }\end{array}$ & PDI & UAI & IDV & MAS & LTO & IVR & CD \\
\cline { 2 - 8 } & Model 1 & Model 2 & Model 3 & Model 4 & Model 5 & Model 6 & Model 7 \\
\hline Constant & $\begin{array}{c}3.088^{* * *} \\
(8.761)\end{array}$ & $\begin{array}{c}4.880^{* * *} \\
(20.988)\end{array}$ & $\begin{array}{c}4.684^{* * *} \\
(19.658)\end{array}$ & $\begin{array}{c}7.916^{* * *} \\
(16.507)\end{array}$ & $\begin{array}{c}3.111^{* * *} \\
(8.852)\end{array}$ & $\begin{array}{c}5.140^{* * *} \\
(22.047)\end{array}$ & $\begin{array}{c}4.876^{* * *} \\
(20.656)\end{array}$ \\
\hline$S C D_{i}$ & $\begin{array}{c}0.233^{* * *} \\
(7.536)\end{array}$ & $\begin{array}{c}-0.150^{* * *} \\
(-8.203)\end{array}$ & $\begin{array}{c}-0.149^{* * *} \\
(-7.309)\end{array}$ & $\begin{array}{c}-0.341^{* * *} \\
(-6.814)\end{array}$ & $\begin{array}{c}0.314^{* * *} \\
(7.486)\end{array}$ & $\begin{array}{c}-0.091^{* * *} \\
(-5.243)\end{array}$ & \\
\hline$C D$ & & & & & & & $\begin{array}{c}-0.117^{* * *} \\
(-5.521)\end{array}$ \\
\hline Controls & YES & YES & YES & YES & YES & YES & YES \\
\hline$F$-statistics & 224.212 & 226.096 & 223.606 & 222.154 & 224.076 & 218.953 & 219.491 \\
\hline Adjusted $R^{2}$ & $50.3 \%$ & $50.5 \%$ & $50.2 \%$ & $50.0 \%$ & $50.3 \%$ & $49.7 \%$ & $49.7 \%$ \\
\hline
\end{tabular}

Notes: The numbers in parentheses are $t$-values. Significance values: ${ }^{\star} p<0.1 ;{ }^{* *} p<0.05 ;{ }^{\star *} p<0.01$.

Table 5. Results of the additional analysis with the moderating effect (source: authors' calculation)

\begin{tabular}{|c|c|c|c|c|c|c|c|}
\hline \multirow{2}{*}{$\begin{array}{c}\text { The } \\
\text { dimension of } \\
\text { Hofstede }\end{array}$} & $P D I$ & $U A I$ & $I D V$ & MAS & LTO & $I V R$ & $C D$ \\
\hline & Model 1 & Model 2 & Model 3 & Model 4 & Model 5 & Model 6 & Model 7 \\
\hline Constant & $\begin{array}{l}3.465^{* * *} \\
(9.664)\end{array}$ & $\begin{array}{l}5.162^{* * *} \\
(20.489)\end{array}$ & $\begin{array}{l}4.579^{* * *} \\
(19.008)\end{array}$ & $\begin{array}{l}9.244^{* * *} \\
(15.382)\end{array}$ & $\begin{array}{l}3.430^{* * *} \\
(9.656)\end{array}$ & $\begin{array}{l}4.945^{* * *} \\
(20.888)\end{array}$ & $\begin{array}{l}4.893^{* * *} \\
(20.965)\end{array}$ \\
\hline$S C D_{i}$ & $\begin{array}{l}0.153^{* * *} \\
(4.351)\end{array}$ & $\begin{array}{l}-0.179^{* * *} \\
(-7.327)\end{array}$ & $\begin{array}{l}-0.093^{* * *} \\
(-3.307)\end{array}$ & $\begin{array}{l}-0.474^{* * *} \\
(-7.602)\end{array}$ & $\begin{array}{l}0.221^{* * *} \\
(4.835)\end{array}$ & $\begin{array}{l}-0.108^{* * *} \\
(-4.564)\end{array}$ & \\
\hline$G D P G$ & $\begin{array}{c}-0.619^{* * *} \\
(-2.810)\end{array}$ & $\begin{array}{l}-0.233^{* *} \\
(-2.482)\end{array}$ & $\begin{array}{l}0.193^{* * *} \\
(3.081)\end{array}$ & $\begin{array}{l}-1.247^{* * *} \\
(-5.392)\end{array}$ & $\begin{array}{l}-0.261^{* *} \\
(-2.310)\end{array}$ & $\begin{array}{c}0.002 \\
(0.040)\end{array}$ & $\begin{array}{l}0.147^{* * *} \\
(6.919)\end{array}$ \\
\hline$S C D_{i} \times G D P G$ & $\begin{array}{l}0.771^{* * *} \\
(3.206)\end{array}$ & $\begin{array}{l}0.317^{* * *} \\
(3.323)\end{array}$ & $\begin{array}{l}-0.095^{*} \\
(-1.804)\end{array}$ & $\begin{array}{l}1.430^{* * *} \\
(5.778)\end{array}$ & $\begin{array}{l}0.418^{* * *} \\
(3.115)\end{array}$ & $\begin{array}{c}0.106^{*} \\
(1.868)\end{array}$ & \\
\hline
\end{tabular}


End of Table 5

\begin{tabular}{|l|c|c|c|c|c|c|c|}
\hline $\begin{array}{c}\text { The } \\
\text { dimension of } \\
\text { Hofstede }\end{array}$ & MDI & UAI & IDV & MAS & LTO & IVR & $C D$ \\
\cline { 2 - 8 } & Model 1 & Model 2 & Model 3 & Model 4 & Model 5 & Model 6 & Model 7 \\
\hline CD $\times$ GDPG & & & & & & & $\begin{array}{c}-0.110^{* * *} \\
(-5.192)\end{array}$ \\
\hline Controls & YES & YES & YES & YES & YES & YES & $\begin{array}{c}0.142^{* * *} \\
(7.108)\end{array}$ \\
\hline F-statistics & 193.716 & 194.626 & 192.238 & 195.446 & 193.551 & 189.616 & 197.252 \\
\hline Adjusted $R^{2}$ & $50.8 \%$ & $50.9 \%$ & $50.6 \%$ & $51.0 \%$ & $50.8 \%$ & $50.2 \%$ & $51.2 \%$ \\
\hline
\end{tabular}

Notes: The numbers in parentheses are $t$-values. Significance values: ${ }^{*} p<0.1 ;{ }^{* *} p<0.05 ;{ }^{* *} p<0.01$.

\section{Robustness tests}

\subsection{Alternative measures of culture values}

Following House et al. (2004) and Schwartz (2006), this study conducts robustness test by alternative measures of culture: GLOBE and Schwartz culture indices. Table 6 presents the regression results for IPO underpricing using GLOBE's five cultural dimensions, which have the similar meaning as Hofstede's cultural values, including in-group collectivism (IC), societal collectivism $(S C)$, gender egalitarianism $(G E)$, and humane orientation $(H M)$ and cultural distance. Table 7 presents the results of the moderating effect. The coefficients of $I C$ and SC in Table 6 and the coefficients of interactions of Models 1 and 2 in Table 7 are all significantly positive. As lower in-group collectivism and societal collectivism have the same meaning as higher individualism, these results are consistent with Hofstede's IDV. Similarly, masculine societies tend to be low on gender egalitarianism, and the coefficient of GE is significantly positive. Thus, a more equal relationship between genders leads to higher underpricing, consistent with Hofstede's MAS. Besides, HM consists with Hofstede's IVR. Further, the coefficient of $C D$ in Table 6 is significantly negative, and the coefficient of $C D^{\star} G D P G$ in Table 7 is significantly positive, consistent with Hofstede's cultural distance. Thus, the findings are robust regarding the GLOBE cultural values.

Table 6. Regression results of the GLOBE culture on IPO underpricing (source: authors' calculation)

\begin{tabular}{|l|c|c|c|c|c|}
\hline The dimension of Hofstede & \multicolumn{2}{|c|}{$I D V$} & $M A S$ & $I V R$ & $C D$ \\
\hline The dimension of GLOBE & IC & $S C$ & $G E$ & $H M$ & $C D$ \\
\hline & Model 1 & Model 2 & Model 3 & Model 4 & Model 5 \\
\hline \multirow{2}{*}{ Constant } & $3.229^{* * *}$ & $\begin{array}{c}2.687^{* * *} \\
(3.423)\end{array}$ & $\begin{array}{c}-1.437^{*} \\
(-1.674)\end{array}$ & $\begin{array}{c}10.278^{* * *} \\
(15.034)\end{array}$ & $\begin{array}{c}4.413^{* * *} \\
(16.680)\end{array}$ \\
\hline \multirow{2}{*}{$S C D_{i}(9.507)$} & $\begin{array}{c}0.185^{* * *} \\
(7.492)\end{array}$ & $\begin{array}{c}0.190^{* * *} \\
(3.208)\end{array}$ & $\begin{array}{c}0.790^{* * *} \\
(7.894)\end{array}$ & $\begin{array}{c}-0.466^{* * *} \\
(-8.063)\end{array}$ & \\
\hline \multirow{2}{*}{$C D$} & & & & & $\begin{array}{c}-0.345^{* * *} \\
(-5.651)\end{array}$ \\
\hline
\end{tabular}


End of Table 6

\begin{tabular}{|l|c|c|c|c|c|}
\hline The dimension of Hofstede & \multicolumn{2}{|c|}{ IDV } & MAS & IVR & $C D$ \\
\hline The dimension of GLOBE & IC & SC & GE & HM & CD \\
\hline & Model 1 & Model 2 & Model 3 & Model 4 & Model 5 \\
\hline Controls & YES & YES & YES & YES & YES \\
\hline F-statistics & 224.093 & 215.867 & 225.204 & 225.687 & 219.751 \\
\hline Adjusted $R^{2}$ & $50.3 \%$ & $49.3 \%$ & $50.4 \%$ & $50.4 \%$ & $49.8 \%$ \\
\hline
\end{tabular}

Notes: The numbers in parentheses are $t$-values. Significance values: ${ }^{*} p<0.1 ;{ }^{* *} p<0.05 ;{ }^{* *} p<0.01$.

Table 7. The moderating effect of economic growth on GLOBE cultural dimensions and IPO underpricing (source: authors' calculation)

\begin{tabular}{|c|c|c|c|c|c|}
\hline The dimension of Hofstede & \multicolumn{2}{|c|}{$I D V$} & MAS & $I V R$ & $C D$ \\
\hline The dimension of GLOBE & IC & $S C$ & $G E$ & $H M$ & $C D$ \\
\hline & Model 1 & Model 2 & Model 3 & Model 4 & Model 5 \\
\hline Constant & $\begin{array}{l}3.645^{* * *} \\
(10.431)\end{array}$ & $\begin{array}{l}4.281^{* * *} \\
(4.926)\end{array}$ & $\begin{array}{l}-2.207^{\star *} \\
(-2.337)\end{array}$ & $\begin{array}{l}11.438^{* * *} \\
(14.094)\end{array}$ & $\begin{array}{l}4.494^{* \star \star} \\
(17.170)\end{array}$ \\
\hline$S C D_{i}$ & $\begin{array}{l}0.109^{* * *} \\
(3.625)\end{array}$ & $\begin{array}{c}0.038 \\
(0.540)\end{array}$ & $\begin{array}{c}0.892^{* * *} \\
(7.903)\end{array}$ & $\begin{array}{l}-0.555^{* * *} \\
(-8.230)\end{array}$ & \\
\hline GDPG & $\begin{array}{c}-0.986^{* * *} \\
(-2.860)\end{array}$ & $\begin{array}{l}-0.702^{* *} \\
(-2.230)\end{array}$ & $\begin{array}{l}1.610^{* * *} \\
(5.537)\end{array}$ & $\begin{array}{l}-1.565^{* * *} \\
(-5.051)\end{array}$ & $\begin{array}{l}0.138^{* * *} \\
(5.304)\end{array}$ \\
\hline$S C D_{i} \times G D P G$ & $\begin{array}{l}1.130^{* * *} \\
(3.109)\end{array}$ & $\begin{array}{l}0.866^{* *} \\
(2.580)\end{array}$ & $\begin{array}{l}-1.449^{* * *} \\
(-5.299)\end{array}$ & $\begin{array}{l}1.731^{* * \star} \\
(5.295)\end{array}$ & \\
\hline$C D$ & & & & & $\begin{array}{l}-0.086^{* * *} \\
(-3.041)\end{array}$ \\
\hline$C D \times G D P G$ & & & & & $\begin{array}{l}0.153^{* * *} \\
(5.751)\end{array}$ \\
\hline Controls & YES & YES & YES & YES & YES \\
\hline F-statistics & 193.500 & 187.734 & 196.634 & 196.978 & 197.331 \\
\hline Adjusted $R^{2}$ & $50.8 \%$ & $50.0 \%$ & $51.2 \%$ & $51.2 \%$ & $51.2 \%$ \\
\hline
\end{tabular}

Notes: The numbers in parentheses are $t$-values. Significance values: ${ }^{*} p<0.1 ;{ }^{* *} p<0.05 ;{ }^{* * *} p<0.01$.

Table 8 presents the results for IPO underpricing using Schwartz's six cultural dimensions, which have the similar meaning as Hofstede's cultural dimensions, including hierarchy $(H R)$, harmony $(H M)$, egalitarian commitment $(E C)$, mastery $(M A)$, and affective autonomy $(A A)$ and cultural distance. Table 9 presents the results of the moderating effect. The coefficient of $H R$ in Table 8 and the interaction of model 1 in Table 9 are both significantly positive, consistent with Hofstede's $P D I$. Likewise, the regression results of $H M$ are consistent with Hofstede's UAI, EC consists with Hofstede's IDV, MA consists with Hofstede's MAS, AA consists with Hofstede's IVR. Moreover, the result of Schwartz's cultural distance is consistent with Hofstede's cultural distance. These results further support the main hypotheses. 
Table 8. Regression results of Schwartz cultural dimensions on IPO underpricing (source: authors' calculation)

\begin{tabular}{|l|c|c|c|c|c|c|}
\hline The dimension of Hofstede & $P D I$ & UAI & $I D V$ & $M A S$ & $I V R$ & $C D$ \\
\hline The dimension of Schwartz & $H R$ & $H M$ & $E C$ & $M A$ & $A A$ & $C D$ \\
\hline & Model 1 & Model 2 & Model 3 & Model 4 & Model 5 & Model 6 \\
\hline Constant & $\begin{array}{c}0.584 \\
(0.806)\end{array}$ & $\begin{array}{c}7.081^{* * *} \\
(11.545)\end{array}$ & $\begin{array}{c}14.120^{* * *} \\
(12.019)\end{array}$ & $\begin{array}{c}15.286^{* *} \\
(11.852)\end{array}$ & $\begin{array}{c}7.399^{* * *} \\
(19.102)\end{array}$ & $\begin{array}{c}3.258^{* * *} \\
(8.764)\end{array}$ \\
\hline$S C D_{i}$ & $\begin{array}{c}0.663^{* * *} \\
(6.568)\end{array}$ & $\begin{array}{c}-0.130^{* * *} \\
(-3.509)\end{array}$ & $\begin{array}{c}-0.774^{* * *} \\
(-7.839)\end{array}$ & $\begin{array}{c}-0.907^{* *} \\
(-4.645)\end{array}$ & $\begin{array}{c}-0.159^{* * *} \\
(-7.435)\end{array}$ & \\
\hline CD & & & & & & $-0.961^{* * *}$ \\
\hline Controls & YES & YES & YES & YES & YES & YES \\
\hline F-statistics & 221.762 & 216.230 & 225.048 & 225.606 & 223.940 & 221.169 \\
\hline Adjusted $R^{2}$ & $50.0 \%$ & $49.4 \%$ & $50.4 \%$ & $50.4 \%$ & $50.2 \%$ & $49.9 \%$ \\
\hline
\end{tabular}

Notes: The numbers in parentheses are $t$-values. Significance values: ${ }^{\star} p<0.1 ;{ }^{\star *} p<0.05 ;{ }^{* \star *} p<0.01$.

Table 9. The moderating effect of economic growth on Schwartz cultural dimensions and IPO underpricing (source: authors' calculation)

\begin{tabular}{|c|c|c|c|c|c|c|}
\hline The dimension of Hofstede & $P D I$ & $U A I$ & $I D V$ & MAS & $I V R$ & $C D$ \\
\hline \multirow[t]{2}{*}{ The dimension of Schwartz } & $H R$ & $H M$ & $E C$ & $M A$ & $A A$ & $C D$ \\
\hline & Model 1 & Model 2 & Model 3 & Model 4 & Model 5 & Model 6 \\
\hline Constant & $\begin{array}{c}1.340^{*} \\
(1.830)\end{array}$ & $\begin{array}{l}7.732^{* * *} \\
(11.817)\end{array}$ & $\begin{array}{l}14.120^{* * *} \\
(12.019)\end{array}$ & $\begin{array}{l}16.259^{* * *} \\
(11.259)\end{array}$ & $\begin{array}{l}7.679^{* * *} \\
(16.880)\end{array}$ & $\begin{array}{l}3.578^{* * *} \\
(9.714)\end{array}$ \\
\hline$S C D_{i}$ & $\begin{array}{l}0.532^{* * *} \\
(5.161)\end{array}$ & $\begin{array}{l}-0.196^{\text {***}} \\
(-4.723)\end{array}$ & $\begin{array}{l}-0.774^{* * *} \\
(-7.839)\end{array}$ & $\begin{array}{l}-0.990^{* * *} \\
(-5.084)\end{array}$ & $\begin{array}{l}-0.174^{* * *} \\
(-6.970)\end{array}$ & \\
\hline$G D P G$ & $\begin{array}{l}-0.471^{* *} \\
(-3.016)\end{array}$ & $\begin{array}{l}-1.665^{\text {***}} \\
(-3.888)\end{array}$ & $\begin{array}{l}2.344^{* * *} \\
(4.297)\end{array}$ & $\begin{array}{l}-1.561^{* * *} \\
(-4.921)\end{array}$ & $\begin{array}{l}-1.693^{* * *} \\
(-3.024)\end{array}$ & $\begin{array}{l}0.154^{* * *} \\
(7.065)\end{array}$ \\
\hline$S C D_{i} \times G D P G$ & $\begin{array}{l}0.652^{* * *} \\
(3.646)\end{array}$ & $\begin{array}{l}1.853^{* * *} \\
(4.156)\end{array}$ & $\begin{array}{c}-2.178^{* * *} \\
(-4.154)\end{array}$ & $\begin{array}{l}1.736^{* * *} \\
(5.159)\end{array}$ & $\begin{array}{l}1.829^{* * *} \\
(3.177)\end{array}$ & \\
\hline$C D$ & & & & & & $\begin{array}{l}-0.859^{* * *} \\
(-5.613)\end{array}$ \\
\hline$C D \times G D P G$ & & & & & & $\begin{array}{l}0.153^{* * *} \\
(7.457)\end{array}$ \\
\hline Controls & YES & YES & YES & YES & YES & YES \\
\hline$F$-statistics & 192.751 & 190.195 & 195.221 & 196.695 & 193.482 & 199.005 \\
\hline Adjusted $R^{2}$ & $50.7 \%$ & $50.3 \%$ & $51.0 \%$ & $51.2 \%$ & $50.8 \%$ & $51.5 \%$ \\
\hline
\end{tabular}

Notes: The numbers in parentheses are $t$-values. Significance values: ${ }^{*} p<0.1 ;{ }^{* *} p<0.05 ;{ }^{* * *} p<0.01$. 


\subsection{Alternative measure of culture distance}

Following Kogut and Singh (1988), and Cai and Zhu (2015), Eq. (6) is used to recalculate the cultural distance between the Chinese A-share market and the listing market. Table 10 presents the results using the alternative measures of cultural distance.

$$
C D_{i}=\frac{\sqrt{\sum_{j=1}^{m}\left(S C D_{i, j}-S C D_{A-\text { share }, j}\right)^{2}}}{m},
$$

Table 10. Regression results of IPO underpricing using alternative measure of cultural distance (source: authors' calculation)

\begin{tabular}{|l|c|c|c|c|c|c|}
\hline & Model 1 & Model 2 & Model 3 & Model 4 & Model 5 & Model 6 \\
\hline Constant & $\begin{array}{c}4.498^{* * *} \\
(18.156)\end{array}$ & $\begin{array}{c}4.734^{* * *} \\
(19.280)\end{array}$ & $\begin{array}{c}4.190^{* * *} \\
(15.846)\end{array}$ & $\begin{array}{c}4.372^{* * *} \\
(16.723)\end{array}$ & $\begin{array}{c}3.259^{* * *} \\
(8.759)\end{array}$ & $\begin{array}{c}3.578^{* * *} \\
(9.705)\end{array}$ \\
\hline CD & $\begin{array}{c}-0.209^{* * *} \\
(-6.821)\end{array}$ & $\begin{array}{c}-0.210^{* * *} \\
(-6.738)\end{array}$ & $\begin{array}{c}-0.344^{* * *} \\
(-7.091)\end{array}$ & $\begin{array}{c}-0.330^{* * *} \\
(-6.687)\end{array}$ & $\begin{array}{c}-0.962^{* * *} \\
(-6.301)\end{array}$ & $\begin{array}{c}-0.859^{* * *} \\
(-5.606)\end{array}$ \\
\hline GDPG & & $\begin{array}{c}0.114^{* * *} \\
(5.549)\end{array}$ & & $\begin{array}{c}0.115^{* * *} \\
(5.545)\end{array}$ & & $\begin{array}{c}0.154^{* * *} \\
(7.063)\end{array}$ \\
\hline CD GDPG & & $\begin{array}{c}0.181^{* * *} \\
(8.049)\end{array}$ & & $\begin{array}{c}0.150^{* * *} \\
(7.390)\end{array}$ & & $\begin{array}{c}0.153^{* * *} \\
(7.444)\end{array}$ \\
\hline Controls & YES & YES & YES & YES & YES & YES \\
\hline F-statistics & 222.368 & 201.128 & 223.044 & 199.931 & 221.145 & 198.962 \\
\hline Adjusted $R^{2}$ & $50.1 \%$ & $51.7 \%$ & $50.1 \%$ & $51.6 \%$ & $49.9 \%$ & $51.5 \%$ \\
\hline
\end{tabular}

Notes: Models 1-2 separately test the effect of Hofstede's cultural distance on IPO underpricing and the moderating effect of economic growth. Models 3-4 separately test the effect of GLOBE's cultural distance. Models 5-6 separately test the effect of Schwartz's cultural distance. The numbers in parentheses are $t$-values. Significance values: ${ }^{\star} p<0.1 ;{ }^{* *} p<0.05 ;{ }^{* *} p<0.01$.

The results show that the closer the distance between the listing markets and the Chinese A-share market, the higher the IPO underpricing for listed companies. Moreover, the rapid economic development restrains the negative relationship between IPO underpricing and culture distance. The results further support the main hypotheses.

\section{Conclusions}

One of the focus of IPO underpricing explanations falls into behavioral theory. Because human perceptions and behaviors are developed and determined by their cultural norms and beliefs, this study argues that investor's subjective perceptions, which mainly depend on their national culture, play an important role in shaping the magnitude of IPO underpricing. Therefore, this study investigates the impact of cultural values and the moderating effect of economic growth on IPO underpricing of Chinese companies listed in different stock markets, which enriches the motivation theory of IPO underpricing. 
Firstly, a finding worthy of special note is that different cultural values have a significant effect on IPO underpricing of companies belonging to the same country. Using Hofstede's six cultural dimensions, the findings have strong evidence to support the hypotheses. According with the literature of investor behavior, investors with different cultural values generate different investment decisions. It is necessary for companies to identify the cultural background of listing markets. Overall, the subcultural dimensions-higher power distance and longer-term orientation, make investors have preference for higher initial returns, inducing managers issuing stocks at lower prices. Thus, IPOs in these markets experience a higher level of underpricing. However, the subcultural dimensions-higher uncertainty avoidance, more individualism, more masculinity, and more indulgence, make investors value more on higher dividends, which results managers issuing stocks at higher prices. As a result, IPOs in these markets experience a lower level of underpricing. More importantly, taking all subcultural dimensions together, the greater the multidimensional cultural distance to Chinese A-share market, the less underpricing IPOs experience for Chinese companies.

Secondly, the findings contribute to the IPO underpricing literature by providing country-level evidence that heterogeneous economic environments help to explain investors behavior and the cross-market IPO underpricing anomaly. In markets with higher levels of power distance, more collectivism, or longer-term orientation, economic growth intensifies the subcultural effect on investors behavior, issuing prices and IPO underpricing, while in markets with higher uncertainty avoidance, masculinity, or indulgence, the influence of subculture on investor behavior will be weakened; the negative relationships are particularly pronounced for low economic growth. Furthermore, given all dimensions, economic growth will restrain the negative effect of cultural distance on IPO underpricing.

In sum, culture plays an indispensable role in international IPO underpricing, economic growth moderates the relationship between culture and IPO underpricing. Recently, more and more Chinese companies are making decisions to enter the overseas markets. Different cultural values emphasize different aspects of investors' perceptions and behaviors. Power distance focuses on the contradiction between investors and issuers. Uncertainty avoidance focuses on the risk aversion in the face of unknown situations. Individualism implies ties between individuals. Masculinity represents individual achievement. Long-term orientation emphasizes subjective purpose of investment. Indulgence implies the code degree of conduct for investors. Consequently, when Chinese companies decide on listing markets and making IPO strategies, the findings suggest that cultural and economic dimensions should be considered, investor behavior should be analyzed, high or low IPO underpricing should be identified.

However, the results only focus on the impact of culture values on IPO underpricing in the first IPO. When companies return to the A-share market after delisting from overseas markets, domestic investors will take the decision-making of overseas investors as reference; IPOs will be impacted by not only two kinds of culture, which neglects how multiculture will affect IPO underpricing. It is the limitation of this study. Thus, the study of the impact of culture on IPO underpricing of the overseas-delisting and re-listing companies will be the focus of further research. 


\section{Funding}

This work was supported by the $<$ National Social Science Fund of China $>$ under Grant [20BLG093], <Tianjin Social Science Planning Project> under Grant [TJGL18-020].

\section{Disclosure statement}

The authors declared no conflict of interest any competing financial, professional, or personal interests from other parties.

\section{Author contributions}

PG and QT conceived the study and were responsible for the design and development of the data analysis. PG was responsible for data collection and analysis. PG and QT were responsible for data interpretation, original draft preparation, and review and editing. QT was responsible for funding acquisition.

\section{References}

Baker, M., \& Wurgler, J. (2006). Investor sentiment and the cross-section of stock returns. Journal of Finance, 61(4), 1645-1680. https://doi.org/10.1111/j.1540-6261.2006.00885.x

Barber, B. M., \& Odean, T. (2008). All that glitters: The effect of attention and news on the buying behavior of individual and institutional investors. Review of Financial Studies, 21(2), 785-818. https://doi.org/10.1093/rfs/hhm079

Cai, K., \& Zhu, H. (2015). Cultural distance and foreign IPO underpricing variations. Journal of Multinational Finance Management, 29, 99-114. https://doi.org/10.1016/j.mulfin.2014.11.003

Chahine, S., Colak, G., Hasan, I., \& Mazboudi, M. (2020). Investor relations and IPO performance. Review of Accounting Studies, 25, 474-512. https://doi.org/10.1007/s11142-019-09526-8

Chang R. P., Rhee, S. G., Stone, G. R., \& Tang, N. (2008). How does the call market method affect price efficiency? Evidence from the Singapore stock market. Journal of Banking \& Finance, 32(10), 2205-2219. https://doi.org/10.1016/j.jbankfin.2007.12.036

Che, L. (2018). Investor types and stock return volatility. Journal of Empirical Finance, 47, 139-161. https://doi.org/10.1016/j.jempfin.2018.03.005

Chourou, L., Saadi, S., \& Zhu, H. (2018). How does national culture influence IPO underpricing? Pacific-Basin Finance Journal, 51, 318-341. https://doi.org/10.1016/j.pacfin.2018.08.015

Cornelli, F., Goldreich, D., \& Ljungqvist, A. (2006). Investor sentiment and pre-IPO markets. Journal of Finance, 61(3), 1187-1216. https://doi.org/10.1111/j.1540-6261.2006.00870.x

Costa, B. A., Crawford, A., \& Jakob, K. (2013). Does culture influence IPO underpricing? Journal of Multinational Finance Management, 23(1-2), 113-123. https://doi.org/10.1016/j.mulfin.2012.12.001

Derrien, F. (2005). IPO pricing in "hot" market conditions: Who leaves money on the table? Journal of Finance, 60(1), 487-521. https://doi.org/10.1111/j.1540-6261.2005.00736.x

Fidrmuc, J. P., \& Jacob, M. (2010). Culture, agency costs, and dividends. Journal of Comparative Economics, 38(3), 321-339. https://doi.org/10.1016/j.jce.2010.04.002

Greenwood, J., \& Jovanovic, B. (1990). Financial development, growth, and the distribution of income. Journal of Political Economy, 98(5), 1076-1107. https://doi.org/10.1086/261720 
Grinblatt, M., \& Hwang, C. Y. (1989). Signalling and the pricing of new issues. Journal of Finance, 44(2), 393-420. https://doi.org/10.1111/j.1540-6261.1989.tb05063.x

Gupta, D. R., Veliyath, R., \& George, R. (2018). Influence of national culture on IPO activity. Journal of Business Research, 90, 226-246. https://doi.org/10.1016/j.jbusres.2018.04.023

Hofstede, G. (2001). Culture's consequences: Comparing values, behaviors, institutions, and organizations across nations. Administrative Science Quarterly, 27(3), 127-131.

Hofstede, G., \& Bond, M. H. (1984). Hofstede’s culture dimensions. Journal of Cross-Cultural Psychology, 15(4), 417-433. https://doi.org/10.1177/0022002184015004003

House, R. J., Hanges, P. J., Javidan, M., Dorfman, P. W., \& Gupta, V. (2004). Culture, leadership, and organizations: The GLOBE study of 62 societies. Sage Publications.

Huang, Y. S., Li, M., \& Chen, C. R. (2019). Financial market development, market transparency, and IPO performance. Pacific-Basin Finance Journal, 55, 63-81. https://doi.org/10.1016/j.pacfin.2019.03.007

Kogut, B., \& Singh, H. (1988). The effect of national culture on the choice of entry mode. Journal of International Business Studies, 19(3), 411-432. https://doi.org/10.1057/palgrave.jibs.8490394

La Porta, R., Lopez-de-Silanes F., Shleifer, A., \& Vishny, R. (2000). Agency problems and dividend policies around the world. Journal of Finance, 55(1), 1-33. https://doi.org/10.1111/0022-1082.00199

La Porta, R., Lopez-de-Silanes, F., Shleifer, A., \& Vishny, R. (1997). Legal determinants of external finance. Journal of Finance, 52(3), 1131-1150. https://doi.org/10.1111/j.1540-6261.1997.tb02727.x

Lakonishok, J., \& Smidt, S. (1986). Volume for winners and losers: Taxation and other motives for stock trading. Journal of Finance, 41(4), 951-974. https://doi.org/10.1111/j.1540-6261.1986.tb04559.x

Lan, J. M., Hao, X. G., \& Lu, S. (2019). A study of the difference of irrational behavior between institutional investors and individual investors. Research on Economies and Management, 40(6), 16-33.

Lenz, H., \& Ostrowski, M. (2005). Auditor choice by IPO firms in Germany: Information or insurance signalling? International Journal of Accounting, Auditing, and Performance Evaluation, 2(3), 300-320. https://doi.org/10.1504/IJAAPE.2005.007677

Lim, K. P., Brooks, R. D. (2010). Why do emerging stock markets experience more persistent price deviations from a random walk over time? A country-level analysis. Macroeconomic Dynamics, 14(S1), 3-41. https://doi.org/10.1017/S1365100509090397

Massa, M., \& Zhang, L. (2020). Local investor horizon clientele and IPO underpricing. Journal of Financial Markets, 100587 (in Press). https://doi.org/10.1016/j.finmar.2020.100587

McGurk, Z., Nowak, A., \& Hall, J. C. (2020). Stock returns and investor sentiment: Textual analysis and social media. Journal of Economics and Finance, 44, 458-485. https://doi.org/10.1007/s12197-019-09494-4

Meluzín, T., Zinecker, M., Balcerzak, A. P., Doubravsky, K., Pietrzak, M. B., \& Dohnal, M. (2018). The timing of initial public offerings - non-numerical model based on qualitative trends. Journal of Business Economics \& Management, 19(1), 63-79. https://doi.org/10.3846/jbem.2018.1539

Nielsson, U., \& Wójcik, D. (2016). Proximity and IPO underpricing. Journal of Corporate Finance, 38, 92-105. https://doi.org/10.1016/j.jcorpfin.2016.03.012

Rija, M. (2019). An empirical analysis of underpricing and oversubscription between venture-backed IPO and non-venture-backed IPO in Italy. International Business Research, 12(4), 143-152. https://doi.org/10.5539/ibr.v12n4p143

Ritter, J. R. (1984). The "hot issue" market of 1980. Journal of Business, 57(2), 215-240. https://doi.org/10.1086/296260

Schwartz, S. H. (2006). A theory of cultural value orientations: Explication. Comparative Sociology, 5(2), 137-182. https://doi.org/10.1163/156913306778667357 
Sherman, A. E. (2005). Global trends in IPO methods: Book building versus auctions with endogenous entry. Journal of Financial Economics, 78(3), 615-649. https://doi.org/10.1016/j.jineco.2004.09.005

Zhang, R., Xian, X., \& Fang, H. (2019). The early-warning system of stock market crises with investor sentiment: Evidence from China. International Journal of Finance \& Economics, 24(1), 361-369. https://doi.org/10.1002/ijfe.1667

Zhou, K., Zhou, B., \& Liu, H. (2020). IPO underpricing and information quality of prospectuses. Singapore Economic Review, 65(6), 1559-1577. https://doi.org/10.1142/S0217590820500289

Zhou, M. S., Zhou, K. H., \& Liu, Y. Z. (2011). Study on the disposition effect of fund investors in China. Review of Investment Studies, 10, 89-99. 